\title{
Effective Stress Management and Employee Productivity in the Nigerian Public Institutions; A Study of National Galary of Arts, Abuja, Nigeria
}

\author{
Marcus Garvey Orji ${ }^{1}$, Gloria Nankling yakubu ${ }^{2}$ \\ ${ }^{I}$ Department of Business Administration, Veritas University, Abuja, Nigeria \\ ${ }^{2}$ National Gallery of Art, Abuja, Nigeria \\ marcusorji@gmail.com
}

\begin{abstract}
The objective of this study was to evaluate the effect of stress management on employee productivity in the Nigerian public institutions with particular emphasis on National Gallery of Arts, Abuja. The study is a survey research and the population of the study consists of employees of the institution with sample size of 171 determined using Taro Yamane's formula. Primary data was used through the administration of questionnaire, and the formulated hypotheses tested by regression method. The findings revealed that there is a significant impact of physical stress management on employee productivity. Furthermore, the results also revealed that there is an insignificant impact of psychological stress management on the employee productivity. Equally there is a significant impact of emotional stress management; environmental stress management and economic stress management on employee productivity. The study concluded that effective stress management can mitigate the negative factors that distressed employees which also have a negative effect on their productivity; and recommended among others that adequate stress management should be incorporated into the fabric of Nigerian public institutions to improve the health of workers and intrapersonal relationships; ergonomic factor that reduces physical stress on a worker's body should be taken into consideration to which in turn can improve productivity; in addition, equity in compensation, feeling of been in control and meaningful task in the setting may help to reduce psychological and emotional stress to improve productivity, also providing some form of financial assistance especially in times of economic distress.
\end{abstract}

Keywords

physical stress; psychological stress; emotional stress; environmental stress; economic stress; employee productivity;

\section{Introduction}

Workplace stress is a continuous problem facing the public sector employees in Nigeria. It generates increasing public and media concern and its cost at work is significantly increasing. Although stress is inherent in life and human behaviour, work place stress is not confined to the work place but it is frequently brought home as well. Increasingly, employers, trade unions, health and safety representatives at work are finding guidance on the nature and causes of the stress problem and on the public sector requirements relating to its prevention and control. A number of factors have to be considered in the study of stress, for example, the multidimensionality of the nature of work place stress, definition of stress, the direct relationship between stress and behaviour, coping with stress and the increasing negative effect of stress on work productivity. The 
multidimensionality of stress, according to Yakubu, (2020), is evidence by the fact that it takes different forms and it concern different fields, for example, Clinical and Applied Psychology, Anthropology, Sociology, Psychosomatic Medicine, Industrial Relations and Epidemiology.

It is useful to clarify that stressors can be derived from any component of the quality of life, whether economic, physical, emotional, social, intellectual or spiritual (Yakubu, 2020). Stress can influence individual behaviour either negatively or positively. Many researchers such as Spielberger (1979), Scott (2013), Manjunatha \& Renukamurthy (2017) believe that work place stress is one of the most important factors affecting productivity because of a direct relationship between individual behaviour and the stress experienced. Bennett (1994) defines stress as a wide collection of physical and psychological symptoms that result from difficulties experienced by an individual while attempting to adapt to an environment. According to Bowin and Harvey (2010), stress occurs with the interaction between an individual and the environment which produces emotional strain affecting a person's physical and mental position. Stress is caused by stressors, which are events that create a state of disequilibrium within an individual.

The factors related to job stress and work conditions need to be defined accurately. Among the factors causing stress in Nigerian Public Institutions are work demands, excessive work load, long duty hours, financial problems, conflict between professional and personal life, problem with patients and those related to the occurrence of death, lack of opportunities for promotion, bullying and sexual harassment (Yakubu, 2020). All these can be summarised under physical stress, psychological stress, emotional stress, environmental stress and economic stress. And in the light of them this study intends to assess the effect of stress management on employee productivity in Nigerian Public Institutions with emphasis on National Gallery of Art Abuja.

\section{Statement of the Problem}

Stress can have various effects on the individual as well as on the organisation. Clearly not only that the individual suffers but the organisation may also be affected by absenteeism, work related accidents, turnover and impaired decision making.

From the organisation's stand point, management may not be concerned when employee experience low to moderate level of stress. Such levels may lead to higher employee performance. But high levels of stress or even low levels sustained over a long period of time can lead to reduced employee performance and thus require action by management. From the individuals stand point even low levels of stress are likely to be perceived as undesirable. What management may consider as 'a positive stimulus that keeps the adrenaline running' is very likely to be seen as 'excessive pressure' by the employee. Stress has an impact on all types of organisations employee, regardless of whether it is a manufacturing industry or a service organisation, and it comes in different forms such as emotional stress, psychological stress, physical stress, environmental stress and economic stress.

\section{Review of Literature}

\subsection{Stress Management}

Folksman (1994) opines that stress management is the need of the hour, however hard we try to go beyond a stress situation; life seems to find new ways of stressing us out, plaguing us with anxiety attacks. Moreover, be it anxiety, mind-body exhaustion or our erring 
attitudes, we tend to overlook the causes of stress, its effects and how to manage stress adequately. In such unsetting moments, we often forget that stressors, if not escapable, are fairly manageable and treatable. Stress management refers to interventions designed to reduce the impact of stressors in the workplace. These can have an individual focus, aimed at increasing an individual's ability to cope with stressors.

This study viewed stress management in line with Newman (2009) who postulates that a major component of stress management is cognitive restructuring or changing the way we think. Our beliefs are the lens through which we look at life. If the expectations we have for ourselves, others and the work do not match reality, we will experience cognitive dissonance. Furthermore, learning about stress management is a vital step to preventing many health problems associated with it. Stress management deals with the reduction of stress and various stressors in our daily lives.

\subsection{Types of Stress}

For the purpose of this study, stress will be categorized into five. They are:

1. Physical stress: There are many physical sources of stress such as work overload, irregular work hours, loss of sleep, noise, improper lighting, trauma (injury, infection, surgery), intense physical labor/over-exertion, environmental pollution (pesticides, herbicides, toxins, heavy metals, inadequate light, radiation, noise, electromagnetic fields), illness (viral, bacterial, or fungal agents), fatigue, inadequate oxygen supply, hypoglycemia (low blood sugar), hormonal and/or biochemical imbalances, dietary stress (nutritional deficiencies, food allergies and sensitivities, unhealthy eating habits), dehydration, substance abuse, dental challenges, and musculo-skeletal misalignments/imbalances (Yakubu, 2020).

2. Psychological stress: when we have psychological stress we can experience a variety of symptoms including anxiety and nervousness, panic attacks, physical sensations.

3. Emotional stress: Emotional stress can be considered to be processed by way of an 'inhibition-implosion' dimension (to implode means to collapse or cause to collapse inwards in a violent manner as a result of external pressure), modulated by dispositional factors (innate, personality and socialization). It can produce marked elevations of BP that can outlast the stimulus. Feelings of tension, conflicted relationship, irritability, restlessness, worries, inability to relax, depression, anxiety, low sex drive, mood swings, compulsive behavior, memory and concentration problems. One can cope with emotional stress by practicing mindfulness, distract yourself, block off time, practice meditation, talk to a therapist, etc.

4. Environmental stress: Stressors that are found in our surroundings are called environmental stressors. Everyday life is full of environmental stressors that cause minor irritations. If you use an alarm clock to wake up, the loud noise from your alarm is an environmental stressor. Extreme temperatures are also environmental stressors and can lead to discomfort. Other common environmental stressors include: environment uncertainties, political, technological uncertainties that influence the organization's structure as well as the employees in that organization. Recent research has linked extreme temperature, crowding and noise with increased levels of discomfort and aggression. The political threats and changes induce stress among employees. New innovations can make an employee's skill and experience obsolete in a very short period of time. (Yakubu, 2020).

5. e) Economic stress is the feeling of stress due to the current state of one's personal finances and/or due to fear about the economy. Although some stress can be healthy, in the way that it can give someone the energy and initiative to take needed actions or encourages the person to challenge him/herself (Yakubu, 2020). 


\subsection{Employee Productivity}

Productivity measures the relationship between the quantity and quality of goods and services produced and the quantity of resources needed to produce them (i.e. factor inputs such as labour, capital and technology) (Okojie, 1995). Mali (1978) defines it thus: 'The measure of how resources are being brought together in organizations and utilized for accomplishing a set of results. It is reaching the highest level of performance with the least expenditure'”.

Productivity in our context is viewed as the instrument for continuous progress, and of constant improvement of activities. It is seen as rate of output per unit of input. Hence, higher productivity connotes achieving the same volume of output with less factor inputs. Thus, increased productivity could result from the reduction in the use of resources, reduction in cost, use of better method or improvement in factor capabilities, particularly labour.

\subsection{Theoretical Review}

This study is in line with theories by Cox and Mackay's Psychological Phenomena and Abraham Maslow's Hierarchy of needs theory.

\section{a. Cox and Mackay's Psychological Model}

Cox Mackay defines stress as a psychological phenomenon. Stress is " a perceptual phenomenon arising from a comparison between the demand on the person and his ability to cope. An imbalance gives rise to the experience of stress and to the stress response" (Cox and Mackay, 1976). According to this model, demands placed on individual results in an increase in performance. There is a point however where optimal performance is reached, and further demands will be to decrease an individual's performance. This relationship is sometimes illustrated by the human performance curve. The most important implication of this model is that it is not so much the actual demands that are significant, it is how we perceive these demands and our ability to cope with them. A person who perceives their ability to cope as weak will experience more stress and vice-versa. Another interesting implication is that mental well-being comes from having an ideal level of stimulation, when we say we are under more stress than we can handle. The only time that we are completely free from stress is at death. Psychological stressors are the most common stressors on modern life. Stress caused by worrying about things that may never happen such as losing our job, or our loved ones being hurt is much more common than actually being in a situation where we are physically threatened.

\section{b. Abraham Maslow's Hierarchy of Needs Theory}

The hierarchy of needs theory was coined by psychologist Abraham Maslow in his 1943 paper 'A Theory of Human Motivation'. The crux of the theory is that individuals' most basic needs must be met before they become motivated to achieve higher level needs. The hierarchy is made up of 5 levels;

1. Physiological: These needs must be met in order for a person to survive, such as food, water and shelter.

2. Safety: Including personal, financial security, health and wellbeing

3. Love/belonging: The need for friends, friendships and family

4. Esteem: The need to feel confident and be respected by others

5. Self-actualization: The desire to achieve everything you possibly can and become the most that you can be. 


\section{Implication:}

Show people the value of their roles, the team will feel respected and motivated to work together. To get staff motivated, support them in other aspects of their lives outside work. For example, give them time to focus on family, offer flexible working hours and make sure they are paid fairly to help them feel financially stable (Yakubu, 2020).

\section{Research Methods}

This study is a survey research, using data collected from both primary and secondary sources. The secondary sources comprise of mainly text books, journals and periodicals, while primary source was descriptive survey questionnaires. The population under study is 300. However, the sample size is 171.

\subsection{Sampling Technique and Sample Size}

The study used the Taro Yamane sampling techniques in selecting the desired respondents, Where;

$$
\begin{aligned}
& \mathrm{N}=\frac{\mathrm{N}}{1+\mathrm{N}(\mathrm{e})^{2}} \\
& \frac{300}{1+3009(0.05)^{2}} \\
& 300 \\
& +300 \times 0.0025 \\
& \frac{300}{1.75}=171
\end{aligned}
$$

The sample size was arrived at 171. Consequently, a total of 171 questionnaires were distributed to respondents in the organization's Headquarters in Abuja, and only 104 was returned valid, representing 61 percent, which is enough to form valid opinion according to Orji (2017). A stratified sampling strategy was adopted in distributing the questionnaire to ensure that junior, middle level, senior and management staff of the organization was included in the sample. Also the study used judgmental method and face to face administration of questionnaire, where the researchers selected units to be sampled based on their knowledge and professional judgment as justified by Orji \& Nduji (2020) and Orji \& Enobun (2018). Close ended questions were used for the questionnaire to easily classify the responses of respondents. The questionnaire was designed using the 5-point likert scale format. Data obtained from the questionnaires administered were analyzed using both descriptive and inferential statistics. The descriptive statistics was the use of simple percentage and mean and inferential statistics using multiple regression technique. The choice of regression is because it explains the effect and relationship between two or more variables of interest. It shows the predictive strength of the influence of the independent variables on the dependent variable as opined by Orji (2017) and Orji, Oyenuga \& Ahungwa (2020). Analysis was carried out using SPSS version 21 (Statistical Package for Social Sciences).

\subsection{Model Specification}

The regression model used for the data analysis is;

$\mathrm{Y}=\mathrm{a}+\beta_{1} \mathrm{X} 1+\beta_{2} \mathrm{X} 2+\beta_{3} \mathrm{X} 3 \ldots+\mathrm{e}$

Thus; $\mathrm{Y}=\mathrm{X}+\beta 1 X 1+\beta 2 X 2+\beta 3 X 3+\beta 4 X 4---+\beta n X n$. 
Where, $\mathrm{a}=$ constant; $\beta=$ Coef ficient of the varriables

$\mathrm{X}=$ Independent Variables; $\mathrm{X} 1=$ Physical stress, $\mathrm{X} 2=$ Psychological stress; $\mathrm{X} 3=$ Emotional stress; X4= Environmental stress; X5= Economic stress

\section{Discussion}

\subsection{Analysis and Findings}

Table 1. Descriptive analysis of Questionnaire items

\begin{tabular}{|c|c|c|c|c|c|c|c|c|c|}
\hline Physical stress & & SD & D & I & $\mathbf{A}$ & SA & Total & Mean & STD \\
\hline $\begin{array}{l}\text { Physical stress affects } \\
\text { employee productivity }\end{array}$ & $\begin{array}{l}\text { No } \\
\%\end{array}$ & $\begin{array}{l}6 \\
5.77\end{array}$ & $\begin{array}{ll}12 \\
11.54\end{array}$ & $\begin{array}{ll}18 \\
17.31\end{array}$ & $\begin{array}{l}27 \\
25.96\end{array}$ & $\begin{array}{l}41 \\
39.42\end{array}$ & $\begin{array}{l}104 \\
100.00\end{array}$ & 202 & 1.23 \\
\hline $\begin{array}{l}\text { Work overload result to } \\
\text { employee stress }\end{array}$ & $\begin{array}{l}\text { No } \\
\%\end{array}$ & $\begin{array}{l}5 \\
4.81 \\
\end{array}$ & $\begin{array}{l}6 \\
5.77 \\
\end{array}$ & $\begin{array}{l}17 \\
16.35 \\
\end{array}$ & $\begin{array}{l}42 \\
40.38\end{array}$ & $\begin{array}{l}34 \\
32.69 \\
\end{array}$ & $\begin{array}{l}104 \\
100.00 \\
\end{array}$ & 0 & .07 \\
\hline $\begin{array}{l}\text { Illness leads to physical } \\
\text { stress }\end{array}$ & $\begin{array}{l}\text { No } \\
\%\end{array}$ & 8.65 & $\begin{array}{l}10 \\
9.62\end{array}$ & $\begin{array}{l}20 \\
19.23 \\
\end{array}$ & $\begin{array}{l}30 \\
28.85 \\
\end{array}$ & $\begin{array}{l}35 \\
33.65 \\
\end{array}$ & $\begin{array}{l}104 \\
100.00\end{array}$ & 3.69 & 1.26 \\
\hline $\begin{array}{l}\text { e affects employee } \\
\text { ctivity }\end{array}$ & No & $\begin{array}{l}1 \\
0.96 \\
\end{array}$ & $\begin{array}{l}14 \\
13.4 \\
\end{array}$ & $\begin{array}{l}17 \\
16.35 \\
\end{array}$ & $\begin{array}{l}36 \\
34.62 \\
\end{array}$ & $\begin{array}{l}36 \\
34.62\end{array}$ & $\begin{array}{l}104 \\
100.00\end{array}$ & 3 & 1.06 \\
\hline al stress & & SD & D & I & $\mathbf{A}$ & SA & & & STD \\
\hline \begin{tabular}{lrr} 
Psychological & \multicolumn{2}{r}{ stress } \\
affects & employee \\
productivity & in & an \\
organization & & \\
\end{tabular} & No & 1.92 & 14 & 18 & 30 & 40 & 104 & 3.88 & 1.12 \\
\hline $\begin{array}{l}\text { Tension, headache result } \\
\text { to psychological stress }\end{array}$ & $\begin{array}{l}\mathrm{Nc} \\
\%\end{array}$ & 4.81 & $\begin{array}{l}8 \\
7.69 \\
\end{array}$ & 18.2 & $\begin{array}{l}39 \\
37.50 \\
\end{array}$ & $\begin{array}{l}33 \\
31.73 \\
\end{array}$ & 100.00 & 3.84 & 1.10 \\
\hline
\end{tabular}

\begin{tabular}{|c|c|c|c|c|c|c|c|c|c|}
\hline $\begin{array}{l}\text { Faint feeling result to } \\
\text { psychological stress }\end{array}$ & $\begin{array}{l}\text { No } \\
\%\end{array}$ & $\begin{array}{l}1 \\
0.96 \\
\end{array}$ & $\begin{array}{l}14 \\
13.46 \\
\end{array}$ & \begin{tabular}{|l|}
16 \\
15.38 \\
\end{tabular} & $\begin{array}{l}35 \\
33.65 \\
\end{array}$ & $\begin{array}{l}38 \\
36.54 \\
\end{array}$ & $\begin{array}{l}104 \\
100.00\end{array}$ & 3.91 & 1.07 \\
\hline $\begin{array}{ll}\text { Heartbeat leads } & \text { to } \\
\text { psychological stress }\end{array}$ & $\begin{array}{l}\text { No } \\
\%\end{array}$ & $\begin{array}{l}2 \\
1.92 \\
\end{array}$ & $\begin{array}{l}14 \\
13.46 \\
\end{array}$ & $\begin{array}{l}18 \\
17.31 \\
\end{array}$ & $\begin{array}{l}30 \\
28.85\end{array}$ & $\begin{array}{l}40 \\
38.46\end{array}$ & $\begin{array}{l}104 \\
100.00\end{array}$ & 3.88 & 1.12 \\
\hline Emotional stress & & SD & D & I & $\mathbf{A}$ & $\mathbf{S A}$ & Total & Mean & STD \\
\hline $\begin{array}{l}\text { Emotional stresses have } \\
\text { effect on employee } \\
\text { productivity in an } \\
\text { organization }\end{array}$ & No & 0.96 & $\begin{array}{l}13 \\
12.50\end{array}$ & $\begin{array}{l}18 \\
17.31\end{array}$ & $\begin{array}{l}39 \\
37.50\end{array}$ & $\begin{array}{l}33 \\
31.73\end{array}$ & $\begin{array}{l}104 \\
100.00\end{array}$ & 3.87 & 1.03 \\
\hline $\begin{array}{l}\text { Depression leads to } \\
\text { emotional stress }\end{array}$ & $\begin{array}{l}\text { No } \\
\%\end{array}$ & $\begin{array}{l}6 \\
5.77 \\
\end{array}$ & $\begin{array}{l}10 \\
9.62 \\
\end{array}$ & $\begin{array}{l}19 \\
18.27 \\
\end{array}$ & $\begin{array}{l}29 \\
27.88 \\
\end{array}$ & $\begin{array}{l}40 \\
38.46 \\
\end{array}$ & $\begin{array}{l}104 \\
100.00\end{array}$ & 3.84 & 1.20 \\
\hline $\begin{array}{l}\text { Conflicted relationship } \\
\text { result to emotional stress }\end{array}$ & $\begin{array}{l}\text { No } \\
\%\end{array}$ & $\begin{array}{l}0 \\
0.00 \\
\end{array}$ & $\begin{array}{l}10 \\
9.62 \\
\end{array}$ & $\begin{array}{ll}18 \\
17.31 \\
\end{array}$ & $\begin{array}{l}30 \\
28.85\end{array}$ & $\begin{array}{l}46 \\
44.23 \\
\end{array}$ & $\begin{array}{l}104 \\
100.00\end{array}$ & 4.08 & 1.00 \\
\hline $\begin{array}{l}\text { Restlessness result to } \\
\text { emotional stress }\end{array}$ & $\begin{array}{l}\text { No } \\
\%\end{array}$ & $\begin{array}{l}3 \\
2.88 \\
\end{array}$ & $\begin{array}{l}10 \\
9.62\end{array}$ & $\begin{array}{l}18 \\
17.31 \\
\end{array}$ & $\begin{array}{l}39 \\
37.50\end{array}$ & $\begin{array}{l}34 \\
32.69\end{array}$ & $\begin{array}{l}104 \\
100.00\end{array}$ & 3.88 & 1.06 \\
\hline $\begin{array}{l}\text { Worries leads to } \\
\text { emotional stress }\end{array}$ & $\begin{array}{l}\text { No } \\
\%\end{array}$ & $\begin{array}{l}7 \\
6.73 \\
\end{array}$ & $\begin{array}{l}9 \\
8.65\end{array}$ & $\begin{array}{l}16 \\
15.38\end{array}$ & $\begin{array}{l}21 \\
20.19\end{array}$ & $\begin{array}{l}51 \\
49.04\end{array}$ & $\begin{array}{l}104 \\
100.00\end{array}$ & 3.96 & 1.26 \\
\hline Environmental stress & & SD & D & I & $\mathbf{A}$ & $\mathbf{S A}$ & Total & Mean & STD \\
\hline $\begin{array}{llr}\text { Environmental } & & \text { stress } \\
\text { affects } & \text { employee } \\
\text { productivity } & \text { in } & \text { an } \\
\text { organization } & & \\
\end{array}$ & $\begin{array}{l}\text { No } \\
\%\end{array}$ & $\begin{array}{l}7 \\
6.73\end{array}$ & $\begin{array}{l}9 \\
8.65\end{array}$ & $\begin{array}{l}19 \\
18.27\end{array}$ & $\begin{array}{l}29 \\
27.88\end{array}$ & $\begin{array}{l}40 \\
38.46\end{array}$ & $\begin{array}{l}104 \\
100.00\end{array}$ & 3.83 & 1.22 \\
\hline $\begin{array}{l}\text { Extreme temperature } \\
\text { result to environmental } \\
\text { stress }\end{array}$ & $\begin{array}{l}\text { No } \\
\%\end{array}$ & $\begin{array}{l}7 \\
6.73\end{array}$ & $\begin{array}{l}6 \\
5.77\end{array}$ & $\begin{array}{l}20 \\
19.23\end{array}$ & $\begin{array}{l}38 \\
36.54\end{array}$ & $\begin{array}{l}33 \\
31.73\end{array}$ & $\begin{array}{l}104 \\
100.00\end{array}$ & 3.81 & 1.14 \\
\hline Technological & No & 7 & 9 & 16 & 37 & 35 & 104 & 3.81 & 1.19 \\
\hline
\end{tabular}




\begin{tabular}{|c|c|c|c|c|c|c|c|c|c|}
\hline $\begin{array}{l}\text { uncertainty result to } \\
\text { environmental stress }\end{array}$ & $\%$ & 6.73 & 8.65 & 15.38 & 35.58 & 33.65 & 100.00 & & \\
\hline $\begin{array}{l}\text { Crowding and noise } \\
\text { leads to environmental } \\
\text { stress }\end{array}$ & $\begin{array}{l}\text { No } \\
\%\end{array}$ & \begin{tabular}{|l|}
4 \\
3.85
\end{tabular} & $\begin{array}{l}5 \\
4.81\end{array}$ & $\begin{array}{l}18 \\
17.31\end{array}$ & $\begin{array}{l}37 \\
35.58\end{array}$ & $\begin{array}{l}40 \\
38.46\end{array}$ & $\begin{array}{l}104 \\
100.00\end{array}$ & 4.00 & 1.05 \\
\hline
\end{tabular}

\begin{tabular}{|c|c|c|c|c|c|c|c|c|c|}
\hline Economic stress & & SD & D & I & $\mathbf{A}$ & SA & Total & Mean & STD \\
\hline $\begin{array}{l}\text { Economic stress affects } \\
\text { employee's productivity } \\
\text { in an organization }\end{array}$ & $\begin{array}{l}\text { No } \\
\%\end{array}$ & $\begin{array}{l}3 \\
2.88\end{array}$ & $\begin{array}{l}14 \\
13.46\end{array}$ & $\begin{array}{l}18 \\
17.31\end{array}$ & $\begin{array}{l}35 \\
33.65\end{array}$ & $\begin{array}{l}34 \\
32.69\end{array}$ & $\begin{array}{l}104 \\
100.00\end{array}$ & 3.80 & 1.12 \\
\hline \begin{tabular}{lr} 
Inadequate & \multicolumn{2}{r}{ personal } \\
finances lead & to \\
economic stress &
\end{tabular} & $\begin{array}{l}\text { No } \\
\%\end{array}$ & $\begin{array}{l}6 \\
5.77\end{array}$ & $\begin{array}{l}7 \\
6.73\end{array}$ & $\begin{array}{l}17 \\
16.35\end{array}$ & $\begin{array}{l}43 \\
41.35\end{array}$ & $\begin{array}{l}31 \\
29.81\end{array}$ & $\begin{array}{l}104 \\
100.00\end{array}$ & 3.83 & 1.10 \\
\hline $\begin{array}{l}\text { Loss of job result to } \\
\text { economic stress }\end{array}$ & $\begin{array}{l}\text { No } \\
\%\end{array}$ & $\begin{array}{l}8 \\
7.69 \\
\end{array}$ & $\begin{array}{l}15 \\
14.42 \\
\end{array}$ & $\begin{array}{l}20 \\
19.23 \\
\end{array}$ & $\begin{array}{l}31 \\
29.81 \\
\end{array}$ & $\begin{array}{l}30 \\
28.85 \\
\end{array}$ & $\begin{array}{l}104 \\
100.00\end{array}$ & 3.58 & 1.25 \\
\hline Employee Productivity & & SD & D & I & $\mathbf{A}$ & $\mathbf{S A}$ & Total & Mean & STD \\
\hline $\begin{array}{l}\text { Employee physical stress } \\
\text { leads to decrease in per } \\
\text { unit input }\end{array}$ & $\begin{array}{l}\text { No } \\
\%\end{array}$ & $\begin{array}{l}4 \\
3.85\end{array}$ & $\begin{array}{l}11 \\
10.58\end{array}$ & $\begin{array}{l}20 \\
19.23\end{array}$ & $\begin{array}{l}34 \\
32.69\end{array}$ & $\begin{array}{l}35 \\
33.65\end{array}$ & $\begin{array}{l}104 \\
100.00\end{array}$ & 3.82 & 1.12 \\
\hline $\begin{array}{l}\text { Psychological stress } \\
\text { affects employee output } \\
\text { per input }\end{array}$ & $\begin{array}{l}\text { No } \\
\%\end{array}$ & $\begin{array}{l}7 \\
6.73\end{array}$ & $\begin{array}{l}9 \\
8.65\end{array}$ & $\begin{array}{l}20 \\
19.23\end{array}$ & $\begin{array}{l}37 \\
35.58\end{array}$ & $\begin{array}{l}31 \\
29.81\end{array}$ & $\begin{array}{l}104 \\
100.00\end{array}$ & 3.73 & 1.17 \\
\hline 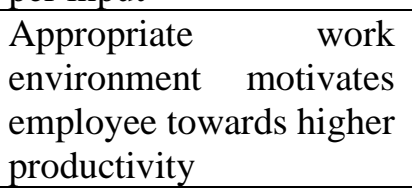 & No & $\begin{array}{l}6 \\
5.77\end{array}$ & $\begin{array}{l}10 \\
9.62\end{array}$ & $\begin{array}{l}19 \\
18.27\end{array}$ & $\begin{array}{l}35 \\
33.65\end{array}$ & $\begin{array}{l}34 \\
32.69\end{array}$ & $\begin{array}{l}104 \\
100.00\end{array}$ & 3.78 & 1.17 \\
\hline 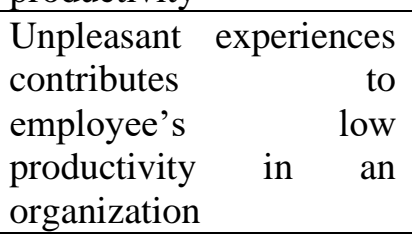 & No & 3.85 & 12.50 & 19.23 & 32.69 & 31.73 & $\begin{array}{l}104 \\
100.00\end{array}$ & 3.76 & 1.14 \\
\hline $\begin{array}{l}\text { Stress leads to decrease } \\
\text { in volume of goods and } \\
\text { services produced per } \\
\text { employee within specific } \\
\text { unit of time }\end{array}$ & No & 3.85 & 7.69 & 16.35 & 37.50 & 34.62 & $\begin{array}{l}104 \\
100.00\end{array}$ & 3.91 & 1.08 \\
\hline
\end{tabular}

Source: field survey, (2020)

This section reports on only the view of the respondents. In respect of questionnaire items on physical stress, the findings on Table 1, show that majority of the respondents indicated that they "strongly agreed" that physical stress affects employee productivity with a mean and standard deviation of 3.82 and 1.23 respectively. In addition, the respondents revealed that they "agree" that work overload result to employee stress with a mean and standard deviation of 3.90 and 1.07 respectively.

Similarly, the respondents revealed that they "strongly agreed" that illness leads to physical stress with a mean and standard deviation of 3.69 and 1.26 respectively. In addition, the respondents revealed that they "strongly agreed" and "agree" that fatigue affects employee productivity with a mean and standard deviation of 3.88 and 1.06 respectively.

In respect of questionnaire items on psychological stress, the findings on the table show that majority of the respondents indicated that they "strongly agreed" that psychological stress affects employee productivity in an organization with a mean and standard deviation of 3.88 and 1.12 respectively, also the respondents revealed that they "agree" that tension, 
headache result to psychological stress with a mean and standard deviation of 3.84 and 1.10 respectively. Furthermore, majority of the respondents revealed that they "strongly agree" that faint feeling result to psychological stress with a mean and standard deviation of 3.91 and 1.07 respectively. Additionally, majority of the respondents revealed that they "strongly agree" that heartbeat leads to psychological stress with a mean and standard deviation of 3.88 and 1.12 respectively.

In respect of questionnaire items on emotional stress, the findings the table show that majority the respondents indicated that they "strongly agreed" that emotional stresses have effect on employee productivity in an organization with a mean and standard deviation of 3.87 and 1.03 respectively. Additionally, majority of the respondents revealed that they "strongly agree" that depression leads to emotional stress with a mean and standard deviation of 3.84 and 1.20 respectively. Moreover, majority of the respondents revealed that they "strongly agree" that conflicted relationship result to emotional stress with a mean and standard deviation of 4.08 and 1.00 respectively. In addition, majority of the respondents revealed that they "agree" that restlessness result to emotional stress with a mean and standard deviation of 3.88 and 1.06 respectively. Also, majority of the respondents revealed that they "strongly agree" that worries leads to emotional stress with a mean and standard deviation of 3.96 and 1.26 respectively.

In respect of questionnaire items on environmental stress, the findings show that majority the respondents indicated that they "strongly agreed" that environmental stress affects employee productivity in an organization with a mean and standard deviation of 3.83 and 1.22 respectively. Likewise, majority of the respondents revealed that they "agree" that extreme temperature result to environmental stress with a mean and standard deviation of 3.81 and 1.14 respectively. Similarly, majority of the respondents revealed that they "agree" that technological uncertainty result to environmental stress with a mean and standard deviation of 3.81 and 1.19 respectively. Additionally, majority of the respondents revealed that they "strongly agree" that crowding and noise leads to environmental stress with a mean and standard deviation of 4.00 and 1.05 respectively.

In respect of questionnaire items on economic stress, the findings on Table 1, show that majority the respondents indicated that they "agree" that economic stress affects employee's productivity in an organization with a mean and standard deviation of 3.80 and 1.12 respectively. Additionally, majority of the respondents revealed that they "agree" that

inadequate personal finances lead to economic stress with a mean and standard deviation of 3.83 and 1.10 respectively. Correspondingly, majority of the respondents revealed that they "agree" that loss of job result to economic stress with a mean and standard deviation of 3.58 and 1.25 respectively.

In respect of questionnaire items on employee productivity, the findings on the table show that majority of the respondents indicated that they "strongly agreed" that employee physical stress leads to decrease in per unit input with a mean and standard deviation of 3.82 and 1.12 respectively. As well, majority of the respondents revealed that they "agree" that psychological stress affects employee output per input with a mean and standard deviation of 3.73 and 1.17 respectively. Furthermore, majority of the respondents revealed that they "agree" that appropriate work environment motivates employee towards higher productivity with a mean and standard deviation of 3.73 and 1.17 respectively. Besides, majority of the respondents revealed that they "agree" that unpleasant experiences contribute to employee's low productivity in an organization with a mean and standard deviation of 3.76 and 1.14 respectively. In addition, majority of the respondents revealed that they "agree" that stress leads to decrease in volume of goods and services produced per employee within specific unit of time with a mean and standard deviation of 3.91 and 1.08 respectively. 


\subsection{Data Analysis}

The method used to analyse the data collected in this study were correlation and multiple regression analysis for the hypotheses testing. Specifically by using correlation and multiple regression analysis, the effect of independent variables on dependent variables was ascertained.

\section{a. Correlation Analysis}

Table 2. Correlation Matrix between physical stress (PHYS), psychological stress (PSYS), emotional stress (EMOS), environmental stress (ENVS), economic stress (ECOS)s and employee productivity (EMPS)

\begin{tabular}{llllllll}
\hline & & PHYS & PSYS & EMOS & ENVS & ECOS & EMPS \\
\hline PHYS & Pearson Correlation & 1 & & & & & \\
& Sig. (2-tailed) & & & & & & \\
PSYS & Pearson Correlation & $.378^{* *}$ & 1 & & & & \\
& Sig. (2-tailed) & .000 & & & & & \\
EMOS & Pearson Correlation & $.426^{* *}$ & $.495^{* *}$ & 1 & & & \\
& Sig. (2-tailed) & .000 & .000 & & & & \\
ENVS & Pearson Correlation & $.263^{* *}$ & $.401^{* *}$ & $.266^{* *}$ & 1 & & \\
& Sig. (2-tailed) & .007 & .000 & .006 & & & \\
ECOS & Pearson Correlation & $.363^{* *}$ & $.417^{* *}$ & $.349^{* *}$ & $.260^{* *}$ & 1 & \\
& Sig. (2-tailed) & .000 & .000 & .000 & .008 & & \\
EMPS & Pearson Correlation & $.559^{* *}$ & $.599^{* *}$ & $.677^{* *}$ & $.495^{* *}$ & $.635^{* *}$ & 1 \\
& Sig. (2-tailed) & .000 & .000 & .000 & .000 & .000 & \\
& N & 104 & 104 & 104 & 104 & 104 & 104 \\
\hline
\end{tabular}

**. Correlation is significant at the 0.01 level (2-tailed).

The results presented in Table 2 indicated firstly, that there is a significant positive correlation between physical stress and employee productivity, with p- value of 0.000 which is less than 0.01 and Pearson Correlation coefficient was 0.559. Secondly, the result also showed that the correlation between psychological stress and employee productivity was significantly positive. The relationship was moderate $(\mathrm{r}=0.599, \mathrm{p}<0.01)$. Thirdly, the result also displayed that the correlation between emotional stress and employee productivity was significantly positive. The relationship was high $(r=0.677, \mathrm{p}<0.01)$. Fourthly, the result also displayed that the correlation between environmental stress and employee productivity was significantly positive. The relationship was moderate $(r=0.495, \mathrm{p}<0.01)$. Lastly, the result in table 2, revealed that there was a significant correlation between economic stress and employee productivity, with p- value of 0.000 which is less than 0.01 and coefficient of correlation $(\mathrm{R})$ of 0.635 . These results imply that there was a significant positive relationship between the study variables.

\section{b. Test of Hypotheses}

\section{Regression Analysis for dimensions of effective stress management and employee productivity}

The null hypotheses of the study were that there are no significant effects of the five dimensions of effective stress management and employee productivity. These hypotheses were tested through multiple regression analysis and the model summary is presented in Table 3, 4 and 5 . 
Table 3. Model Summary

\begin{tabular}{llllll}
\hline Model & $\mathrm{R}$ & R Square & Adjusted R Square & $\begin{array}{l}\text { Std. Error } \\
\text { Estimate }\end{array}$ & of the \\
\hline 1 & $.860^{\mathrm{a}}$ & .740 & .727 & .28006 & \\
\hline
\end{tabular}

a. Predictors: (Constant), ECOS, ENVS, EMOS, PHYS, PSYS

Note: $\mathrm{ECOS}=$ Economic Stress, ENVS= Environmental Stress, EMOS= Emotional Stress, PHYS= Physical Stress, PSYS= Psychological Stress

Source: Field Survey, 2020.

The results in Table 3 indicated that there were significant effects of the three dimensions of effective stress management on employee productivity in which $\mathrm{R}^{2}$ was 0.860 implying that $86 \%$ of employee productivity was explained by physical stress, psychological stress, emotional stress, environmental stress and economic stress. This shows that an increase in all these dimensions as a whole by one unit causes an increase in employee productivity by 0.860 .

Table 4. ANOVA ${ }^{\mathrm{a}}$

\begin{tabular}{|c|c|c|c|c|c|c|}
\hline Model & & Sum of Squares & Df & Mean Square & $\mathrm{F}$ & Sig. \\
\hline \multirow[t]{3}{*}{1} & Regression & 21.893 & 5 & 4.379 & 55.828 & $.000^{\mathrm{b}}$ \\
\hline & Residual & 7.686 & 98 & .078 & & \\
\hline & Total & 29.579 & 103 & & & \\
\hline
\end{tabular}

a. Dependent Variable: EMPS

b. Predictors: (Constant), ECOS, ENVS, EMOS, PHYS, PSYS

Note: $E C O S=$ Economic Stress, ENVS= Environmental Stress, EMOS= Emotional Stress, PHYS= Physical Stress, PSYS= Psychological Stress

Analysis of Variance result for the effect of the five dimensions of effective stress management on employee productivity is shown in Table 4. above in which computed FStatistics value was 55.828 which is greater than the critical value of 3.85 and $p$ value was 0.000 which was less than 0.05 meaning that the effect of the five dimensions of effective stress management on employee productivity was significant. Thus the null hypotheses was rejected and concluded that there was a significant effect of all the five dimensions of effective stress management on employee productivity.

Table 5. Coefficients ${ }^{\mathrm{a}}$

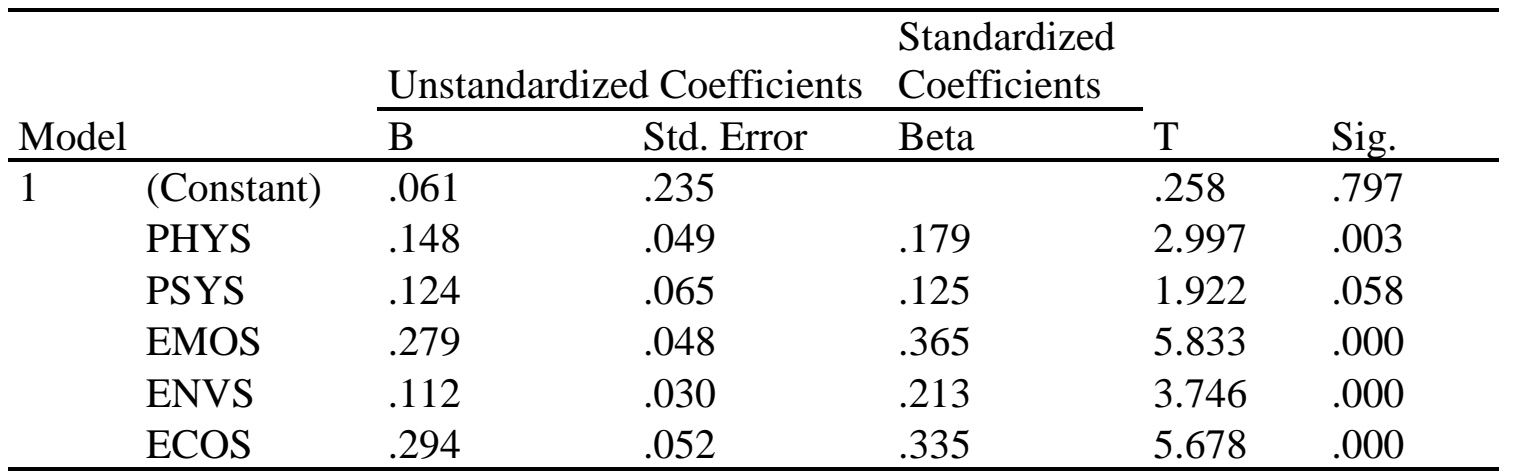

a. Dependent Variable: EMPS

Note: ECOS= Economic Stress, ENVS= Environmental Stress, EMOS= Emotional Stress, PHYS= Physical Stress, PSYS= Psychological Stress 
The results presented in table 5 shows the fitness of model used of the regression model in explaining the study variables. Physical stress, psychological stress, emotional stress, environmental stress and economic stress were found to be satisfactory variables in explaining in employee productivity. Regression of coefficients results in table 5 shows that the constant is .061 while the variables which are statistically significant for the equation are: Physical stress has a significant positive effect on employee productivity $(r=0.148, p=0.003)$. Similarly, emotional stress management has a significant positive effect on employee productivity $(\mathrm{r}=0.279, \mathrm{p}=0.000)$. Likewise, environmental stress management has a significant positive effect on employee productivity $(\mathrm{r}=0.112, \mathrm{p}=0.000)$. Equally, economic stress management has a significant positive effect on employee productivity ( $\mathrm{r}=0.294$, $\mathrm{p}=0.000$ ). However, psychological stress management has an insignificant positive effect on employee productivity $(\mathrm{r}=0.124, \mathrm{p}=0.058)$.

This implies that a single unit increase in any of the independent variables (physical stress, psychological stress, emotional stress, environmental stress and economic stress) results to increase in employee productivity at the rate of $0.179,0.125,0.365,0.213$ and .335 respectively.

$\mathrm{EMPS}=0.061+0.148 \mathrm{X} 1+0.124 \mathrm{X} 2+0.279 \mathrm{X} 3+.0 .112 \mathrm{X} 4+0.294 \mathrm{X} 5$, Where X1 $=$ PHYS, X2= PSYS, X3 = EMOS, X4 = ENVS and X5= ECOS

\subsection{Discussion of Findings}

The findings of hypothesis one revealed that there is a significant impact of physical stress management on employee productivity in National Gallery of Arts, Abuja. Thus, many physical sources of stress such as work overload, irregular work hours, loss of sleep, noise, improper lighting etc which can affect employee productivity. The results support prior researches conducted by Di Martino, (2003) and Yakubu (2020) who found that the level of stress within a role varies because of individual differences in mindset, age, gender, and their performance in job.

The results of hypothesis two revealed that there is an insignificant impact of psychological stress management on employee productivity in National Gallery of Arts, Abuja. This implies that psychological stress does not really affect employee productivity in the survey area. This result may be because of all stress influences, the psychological ones are the most subtle and difficult to deal with because most people refuse to accept emotional distress. People are more willing to admit to physical disorders but usually will deny psychological pain. This result is also supported by Hoboubi, et al (2017) who examined the impact of job stress and job satisfaction on workforce productivity in an Iranian petrochemical industry and found that the relationship between job stress and productivity indices was not statistically significant.

The results of hypothesis three revealed that there is a significant impact of emotional stress management on employee productivity in National Gallery of Arts, Abuja. Emotional stress can be particularly painful and be challenging to deal with, can take more of a toll than many other forms of stress. It can produce marked elevations of BP that can outlast the stimulus. Feelings of tension, conflicted relationship, irritability, restlessness, worries, inability to relax, depression, anxiety, low sex drive, mood swings, compulsive behavior, memory and concentration problems. This result is consistent with the result of studies conducted by Swaminathan and Rajkumar (2013) who conducted a study that focused on the levels of stress among the age group, profession, different varieties of jobs, hours of work and the influence of work environment on the degree of stress faced by employees.

The results of hypothesis four revealed that there is a significant impact of environmental stress management on employee productivity in National Gallery of Arts, 
Abuja. Work environment plays an important role in an organization. Most of the problems faced by employees are related to working environment. The level of productivity can be increased through developing a conducive working environment in the organization. This result is similar to the study of Awan, and Tahir (2015) who examined the impact of working environment on productivity of employees. It was observed that the factors like supervisor support, relation with co-workers, training and development, attractive and fast incentives and recognition plans, adequate work load at work place are helpful in developing a working environment that has positive impact on employee's level of productivity in the organizations.

The results of hypothesis five revealed that there is a significant impact of economic stress management on employee productivity in National Gallery of Arts, Abuja. This could be because inadequate personal finances, loss of job, and weak purchasing power is a serious factor to economic stress (Yakubu, 2020).

\section{Conclusion}

Employees are the most valuable resource of every organization. Without competent employees, no organization can succeed to outrun its competitors. The success of the organization depends on the employees. The study draws its conclusion from the fact that effective stress management can mitigate the negative factors that distressed employees which have a negative effect on their performance. So, for a public institution to be more successful, it is necessary for the employees to be s stress free for them to perform well.

\section{References}

Awan, A. G., \& Tahir, M. T. (2015). Impact of working environment on employee's productivity: A case study of Banks and Insurance Companies in Pakistan. European Journal of Business and Management, 7(1), 329-345.

Bowin, R.B. \& Harvey D. (2010). Human Resource Management an Experiential Approach. 2nd Ed. New Jersey: Prentice Hall.

Cox, T. \& Mackay, C. (1976). A Psychological Model of Occupational Stress. Retrieved from https://en.wikipedia/wiki/Huns Selye

Di Martino, V. (2003). Relationship between Work Stress and Workplace Violence in the Health Sector, 5th Eddition. USA: McGraw Hill

Folksman, G.H. (1994). Managing Stress Subjectivity and Power in the Workplace. Thousand Oaks, cliff, sage Wharton A.S. and Brikson. R.I. 457.

Hoboubi, N., Choobineh, A., Ghanavati, F. K., Keshavarzi, S., \& Hosseini, A. A. (2017). The impact of job stress and job satisfaction on workforce productivity in an Iranian petrochemical industry. Safety and health at work, 8(1), 67-71

Kyko O.C. (2005) Instrumentation: Know Yourself and Others. New York: Longman

Mali, P. (1978), Improving Total Productivity, New York: John Wiley and Sons Inc

Mark, A.D. (2012). Stress and Its Effect on Employee Productivity: A Case Study of Ghana. Ports and Harbour Authority Takoradi. Retrieved from: Wikipedia

Manjunatha, M. K., \& Renukamurthy, T. P. (2017). Stress among banking employee-A literature review. Int. J. Res. Granthaalayah, 5, 207-213

Newman, B. A. (2009). Managing workplace stress. San Franscioso: Jossy Bass Publication limited.

Okojie, C. E. E. (1995), Human Capital Investment for Productivity Growth in Nigeria, The Nigerian Economic and Financial Review 
Orji MG (2017) Impact of Personality Factors on Consumer Buying Behavior of Textile Materials in South Eastern Nigeria. PhD Thesis, Department of Business Administration, Ahmadu Bello University, Zaria, Nigeria,

Orji, M.G, Enobun, P.N (2018). Effect of Work Environment on Teacher Commitment to Duty in Selected Secondary Schools of South Eastern Nigeria, 'Management'" (MANA) International Technology and Science Publishers (ITS) United Kingdom. Vol. 1.PP 61- 78.www.itspoa.com/journal/mana

Orji, M.G \& Nduji, R, (2020) Business Sustainability and Challenges of Climate Change in Nigerian Indigenous Automobile Companies. A case study of Innoson Motors Ltd, Nnewi, Nigeria Konfrontasi 'Journal: Culture, Economy and Social Changes, 9 (1) PP, 77-90

Orji, M.G, Oyenuga, M \& Ahungwa, A (2020) Effects of Sales Promotion on Consummer Buying Behavior of Food Seasoning Among Nigerian House Holds: A Case Study of Nestle Maggi Naijapot' Budapest International Research and Critics Institute-Journal (BIRCI-Journal) Volume 3, ( 1), PP: 134-149

Opperman C.S (2002). Tropical Business Issues. Partner Price Water House Coopers

Robbins, I.E. (2005). Personal and Organizational Strategies for Handling Job Stress Personnel Psychology. Spring: New York, Spring publisher Ltd

Scott, E. (2013). Eight Keys to Stress Management. Retrieved from: www.norton.com

Sherman, M. Bahlander, S. \& Snell, B. (1996). Managing Human Resources, 10th Edition. Cincinnati Ohio: South West College Printing ++

Spielberger, C. (1979). Understanding stress and anxiety. London: Harber and Row Publishers, p. 4.

Swaminathan, P, \& Rajkumar, S (2013) 'Stress Levels in Organizations and their Impact on Employees' Behaviour', BVIMR Management Edge, 6, 1, pp. 79-88, Business Source Complete, EBSCOhost,Ritchie, S. \& Martin, P. (1999). Motivation Management. Hampshire: Gower Publishing Limited.

Yakubu, G.N (2020) Effective Stress Management and Employee Productivity in the Nigerian Public Institutions; A case study of National Gallery of Art, Abuja' Unpublished MSc Thesis, National Open University of Nigeria, Abuja 